\title{
Türk sofralık yeşil zeytinlerin antioksidan özellikleri üzerine İspanyol yöntemi ile işlemenin etkisi
}

\author{
Elif SAVAŞ*
}

Balıkesir Üniversitesi, Mühendislik Fakültesi, Gıda Mühendisliği Bölümü, Çăğış kampüsü, Balıkesir

Gelis Tarihi (Received Date): 23.05.2019

Kabul Tarihi (Accepted Date): 22.10.2019

\section{$\ddot{\mathbf{O z}}$}

Akhisar Bölgesi Türkiye'den hasat edilen üç Türk zeytin çeşidi (Domat, Edremit, Gemlik) ile gerçekleştirilen bu çalışmanın amacı, Ispanyol Yöntemi ile sofralık zeytine işlemenin toplam fenolik madde ve antioksidan kapasiteye etkisini belirlemektir. Zeytin ekstraktlarının toplam fenol içeriği Folin-Ciocalteu yöntemi ile, antioksidan kapasite ise ferric tiyosiyanat indirgeme kapasitesi ve hidrojen peroksit giderme kapasitesi yöntemleri ile belirlenmiştir. Çizilmiş ve çizilmemiş zeytinler salamura değişimi ((6\% $\%(w / v) ~ N a C l)$ ve kontrol örneği olarak alkali $(1 \%(w / v) \mathrm{NaOH})$ uygulamast ile actlı giderme işlemine tabi tutulmuştur. Alkali ile acılık giderme işlemi oleuropein miktarlarında \% 78 oranında azalmaya neden olmakla birlikte sirastyla Edremit, Domat ve Gemlik çeşitlerinin toplam fenolik madde içeriklerinde \% 70.51, \% 70.47 and \% 50.44 düzeylerinde azalma görülmüş̧ür.

Anahtar kelimeler: $\mathrm{H}_{2} \mathrm{O}_{2}$ giderme, toplam fenol, zeytin, Edremit, domat, Gemlik.

\section{Influence of Spanish style processing on antioxidant properties of Turkish green table olives}

\begin{abstract}
The study was performed on three Turkish olive cultivars from Akhisar region in Turkey (Domat, Edremit, Gemlik) to determine the effect of Spanish style processing on total phenolic compounds and antioxidant capacity. Total polyphenol content was estimated with the Folin-Ciocalteau assay, the antioxidant activity of olive extracts was determined
\end{abstract}

\footnotetext{
*Elif SAVAŞ, esavas@balikesi.edu.tr, http://orcid.org/0000-0002-4878-0013
} 
according to the ferric thiocyanate methodand hydrogen peroxide scavenging assay. Scratched and unscratched olive samples were debittered by brine replacement (6\% $(w / v)$ $\mathrm{NaCl})$ and alkaline $(1 \%(\mathrm{w} / \mathrm{v}) \mathrm{NaOH})$ treatment as control. Alkali treatment for debittering, was decreased oleuropein amounts $78 \%$, however, has led to an important loss of total phenolic compounds with a reduction rate of $70.51 \%, 70.47 \%$ and $50.44 \%$, for Edremit, Domat and Gemlik varieties, respectively.

Keywords:H2O2 scavenging, total phenol, olive, Edremit, domat, Gemlik.

\section{Giriş}

Zeytin ve zeytinyağı Akdeniz diyetinin vazgeçilmez sağlıklı bileşenlerini oluşturmaktalar ve bu nedenle fonksiyonel gıda olarak ifade edilmektedirler [1-3]. Türkiye önemli bir sofralık zeytin üreticisi ve tüketicisi ülke olarak bilinmektedir. Sofralık zeytinde bulunan fenolik maddeler lezzet, aroma, yapı gibi pekçok özelliğin oluşumunda etkili olmakla birlikte, zeytinin antioksidan özelliğinden sorumludur. Teknik olarak fenolik bileşikler indirgeyici ajan, hidrojen verici ve tekli oksijen baskılayıcı olarak rol oynamaktadır [3]. Bu bileşikler, serbest radikallerin temizlenmesi ve işleme ile depolama sürecinde gıdaların bozulmasının en önemli nedenlerinden biri olan lipid peroksidasyon sürecinin geciktirilmesi yoluyla raf ömrünü artırmaktadır [4-6]. Aynı zamanda antioksidanlar, insan bedenini serbest radikal ve reaktif oksijen türlerinin etkilerine karşı da korumaktadırlar. Lipid peroksidasyonunun yanı sıra birçok kronik hastalığın ilerlemesini geciktirirler [7]. Son dönemde birçok kronik hastalıkla ilişkilendirilen reaktif oksijentürlerine olan ilgi gittikçe artmaktadır. Bu bileşikler, süperoksit anyon radikalleri $\left(\mathrm{O}^{-}\right)$, hidroksil radikalleri $(\mathrm{OH}), \mathrm{H}$ ve $\mathrm{O}$ gibi serbest olmayan radikal türleri ile tekli oksijen $\left(\mathrm{O}_{2}\right)$ içeren serbest radikalleri içeren çeşitli aktif oksijen formlarıdır[8]. Bitkisel kaynaklarda bulunan ve zararlı reaktif oksijen türlerinin vücutta bıraktığı hasarlara karşı koruyucu etki gösteren doğal ve güvenli antioksidan kaynaklarını belirlemeye yönelik çalışmalar hız kazanmıştır. İnsan beslenmesi açısından önemli olduğu kadar, gıda raf ömrünün kısalmasına neden olan reaktif oksijen türlerinin lipid peroksidasyonu yolu ile gıdalarda besinsel ve duyusal özelliklerin kaybına neden oldukları düşünüldüğünde antioksidanların önemi daha da artmıştır [9]. Bitkisel kökenli gıdalarda doğal olarak bulunan antioksidan bileşikler çeşit [10,11], olgunlaşma derecesi [12], sulama rejimleri [13], iklim ve seçilen ekstraksiyon yöntemleri zeytinlerin antioksisan özelliklerini etkileyen faktörler olarak bildirilmektedir. Sofralık zeytin üretiminde uygulanan yöntemler süresince birçok farklı işlem ve süreç farklı mekanizmalarla fenolik bileşen miktarı ve türü üzerinde etkili bulunmuştur [10-18]. Doğal siyah sofralık zeytin üretiminde fermentasyon süresince asit hidrolizi son üründe ana fenolik bileşen olarak bilinen hidroksitirozol oluşumuna neden olmaktadır. Antosiyaninlerin polimerizasyonu, zeytinlerin son renk gelişiminin sebebidir [14-19].

İspanyol yöntemi endüstriyel ölçekte sofralık yeşil zeytin üretiminde en çok uygulanan yöntemler arasındadır. Bu metot, hızlı, güvenilir ve standart üretime imkan verdiği için tercih edilmektedir. İspanyol yöntemi ile yeşil zeytin işleme, $\mathrm{NaOH}$ uygulaması ile glikozitlerin hidrolizini gerçekleştirerek, bol miktarda hidroksitirozol salınımına yol açmaktadır. Benzer şekilde verbaskosit hidrolizinin neden olduğu kafeik asidin formasyonu da gözlenmektedir [14]. 
Üretimde yer alan her yanlış adım, tüketiciyi doğal gıda kaynaklarından uzaklaştırması yaısıra beklenen sağlık etkilerinden yararlanma olasılığını azalmasına yol açar. Prosesleri yönlendirecek optimum çözümler bulmak için problemleri doğru belirlemek önemli bir noktadır. Bu amaçla, işlenmiş zeytin ürünlerindeki antioksidan kayıplarını ortaya çıkarmak büyük bir öneme sahiptir. Bu durum besin değeri bakımından gıda kaynaklarından ne kadar yararlanılabileceğini de göstermektedir. Bu çalışmada Türk yeşil sofralık zeytinlerini (Olea europea $L$ ) İspanyol yöntemi ile işleme sonrası antioksidan özelliklerindeki değişim etkisi araştırılmıştır.

\section{Materyal ve Yöntem}

\section{1. Örnek koleksiyonu ve hazırlanmast}

Üç farklı Türk çeşidi (Gemlik, Domat ve Edremit) yeşil olgunluktaki zeytinler, 2012 y1lı Kasım ayında Akhisar Bölgesi’nden hasat edildikten sonra, sap ayırma, yaprak ve çöpleri ayıklama ve en son yıkama işlemine alınmıştır. Sınıflandırma ve boylama işlemlerini takiben zeytinlerin kg daki dane sayıları belirlenmiştir. Zeytinler seçilen ağaçlardan elle toplanarak işlenmiştir. Sofralık zeytin üretimi için doğal yöntem ve İspanyol yöntemi uygulanmıştır. İspanyol yöntemi için zeytinler alkali çözeltisi $(10 \mathrm{~g} / \mathrm{L} \mathrm{NaOH})$ içinde 20 saat süresince, alkali meyve etinin \%65'ine penetre oluncaya dek acllık giderme işlemine tabi tutulmuştur. Ardından alkali kalıntısını gidermek için yaklaşık 12 saat süreyle asitle yıkama $(0.5 \mathrm{~g} / 100$ $\mathrm{mL}$ sitrik asit içinde) gerçekleştirilmiş̧ir. Sonra zeytinler salamura içinde $(\% 6 \mathrm{NaCl}) \mathrm{pH}$ 4.5'a gelinceye dek fermentasyona bırakılmışlardır.

İkinci yöntem olarak zeytinler doğal işleme yöntemi olarak bilinen salamura değişimi yöntemi ile işlenmişlerdir. $\mathrm{Bu}$ geleneksel işleme yöntemi Anadolu'da yüzyıllardır kullanılmakta olan bir yöntemdir. Yöntem, 24 saat süresince zeytinlerin $\mathrm{CaCl}_{2}(1 \mathrm{~g} / 100 \mathrm{ml})$ çözeltisi içerisinde bekletildikten sonra salamura $(\mathrm{NaCl}: 6 \mathrm{~g} / 100 \mathrm{~mL})$ ile yer değiştirmesi ile gerçekleştirilmektedir. Haftada iki kez salamura değişimi yapılarak acılık giderme işlemi toplam 33 günde tamamlanmıştır. Burada ölçüt oleuropein adı verilen fenolik glikozitten kaynaklanan acı tadın büyük ölçüde yok olmasıdır. Bu ön işlemin ardından zeytinler $6 \mathrm{~g} / 100$ $\mathrm{mL} \mathrm{NaCl}$ içeren salamura içerisinde fermentasyona bırakılmışlardır. Kontrol grupları bütün çeşitlerin işlenmemiş meyvelerinden oluşmaktadır.

Analizlerde kullanmak üzere zeytin örneklerinden ekstrakt elde edilmiş, daha sonra bu ekstraktlardan zeytin tozu elde edilmiştir. Bu amaçla taze ve işlenmiş zeytinler sıvı nitrojen kullanıldıktan sonra Micra XRT(Heitersheim / Deutschland) marka homojenizatör yardımıyla homojenize edilmişlerdir. Örnekler analize alınıncaya dek $+4^{\circ} \mathrm{C}$ 'de depolanmışlardır. Bütün çeşitlerde denemeler başlangıç, ispanyol yöntemi sırasında ve fermentasyondan 4 ay sonra gerçekleştirilmiştir. Zeytin tozu $2 \mathrm{dk} 100 \mathrm{~mL}$ etanol içinde homojenize edildikten sonra elde edilen homojenizatlar analize alınmıştır.

\subsection{Kimyasallar}

Araştırmada kullanılan kimyasallar analitik saflıkta olup Sigma (Sigma- Aldrich GmbH, Sternheim, Germany) ve Merck (KGaA, Darmstadt, Germany) firmalarından temin edilmiştir. 


\subsection{Ferrik tiyosiyanat (FTC) yöntemi ile antioksidan kapasitenin belirlenmesi}

Zeytin ekstraktlarının antioksidan kapasiteleri ferrik tiyosiyanat (FTC) yöntemiyle gerçekleştirilmiştir [20]. Stok çözeltisinin $2.5 \mathrm{~mL}$ sodyum fosfat tamponu (0.04 M, pH 7.0) içinde seyreltilmesiyle farklı konsantrasyonlarda zeytin çözeltileri (1 - $5 \mathrm{~mL}$ ) hazırlanmış ve bunlar sodyum fosfat tamponundaki $2.5 \mathrm{~mL}$ linoleik asit emülsiyonuna eklenmiştir $(0.04 \mathrm{M}$, $\mathrm{pH}$ 7.0).Linoleik asit emülsiyonu, $15.5 \mu \mathrm{L}$ linoleik asit, emülgatör olarak $17.5 \mathrm{mg}$ Tween20 ve $5 \mathrm{~mL}$ fosfat tamponu ( $\mathrm{pH} \mathrm{7.0)}$ homojenize edilerek hazırlanmıştır. Kontrol, $2.5 \mathrm{~mL}$ linoleik asit emülsiyonu ve $2.5 \mathrm{~mL}, 0.04 \mathrm{M}$ sodyum fosfat tamponundan ( $\mathrm{pH} 7.0$ ) oluşmuştur. Reaksiyon karışımları $(5 \mathrm{~mL}) 37^{\circ} \mathrm{C}$ 'de polietilen kaplarda inkübasyona bırakılmıştır. Peroksit düzeyleri 500 nm'de absorbans okunarak belirlenmiştir. Linoleik asit peroksidasyonu sırasında oluşan peroksitler, $500 \mathrm{~nm}$ 'de maksimum absorbansı olan ferrik tiyosiyanat yöntemiyle bir kompleks oluşturan $\mathrm{Fe} 2+$ ile $\mathrm{Fe} 3$ + '1 okside edecektir. Çalışma aşamasınca her 5 satte bir maksimuma ulaşılıncaya kadar bu durum tekrarlanmıştır. Yüzde inhibisyon bu noktada (30 saat) hesaplanmıştır. Zeytin ekstraktı içermeyen çözeltiler kör (şahit) örnek olarak kullanılmıştır. Linoleik asit emülsiyonundaki lipid peroksidasyonu aşağıdaki eşitlik kullanılarak hesaplanmıştır:

\section{Lipid peroksidasyon $(\%)=(100-A \ddot{O} / A K) \times 100$}

AK: Kontrol reaksiyon absorbansı (sadece linoleik asit emülsiyonu ve sodyum fosfat tampon çözeltisine ait absorbans)

AÖ: Örnek absorbansı (zeytin ekstraktlarını içeren) (20).

\subsection{Hidrojen peroksit giderme aktivitesi}

Hidrojen peroksit giderme aktivitesi Ruch ve ark. (1989)'na göre gerçekleştirilmiştir [21]. Yöntemin prensibi, $\mathrm{H}_{2} \mathrm{O}_{2}$ 'in oksidasyonu nedeni ile absorbansındaki azalmanın belirlenmesidir. $43 \mathrm{mM} \mathrm{H} \mathrm{O}_{2}$ çözeltisi $0.1 \mathrm{M}$ fosfat tampon çözeltisi (pH 7.4) kullanılarak hazırlanmıştır. $3.4 \mathrm{~mL}$ fosfat tampon çözeltisi içinde $1 \mathrm{~mL}$ zeytin ekstraktları hazırlanarak $0.6 \mathrm{~mL} \mathrm{H} \mathrm{H}_{2} \mathrm{O}_{2}$ çözeltisi ilave edildikten sonra $230 \mathrm{~nm}$ de absorbansı kaydedilmiştir. Şahit çözelti $\mathrm{H}_{2} \mathrm{O}_{2}$ içermeyen fosfat çözeltisi kullanılarak hazırlanmıştır. Deney ortamında hidrojen peroksit konsantrasyonu $(\mathrm{mM})$ standart kurve kullanılarak belirlenmiştir. Zeytin ekstraktlarının $\mathrm{H}_{2} \mathrm{O}_{2}$ giderme yüzdesi aşağıdaki eşitlik kullanılarak hesaplanmıştır:;

$\mathrm{H}_{2} \mathrm{O}_{2}$ giderme etkisi $(\%)=(1-\mathrm{AO} / \mathrm{AK}) \times 100$; AK; Kontrol absorbansı ve AÖ; zeytin ekstraktlarının bulunduğu örnek absorbansı [20].

\subsection{Toplam fenol içeriğinin belirlenmesi}

Zeytin ekstraktlarındaki toplam suda çözünür fenolik bileşenler Folin-Ciocalteu çözeltisi kullanılarak gallik asit standart kurvesi üzerinden belirlenmiştir [22]. $1 \mathrm{~g}$ ekstrakt içeren 1.0 $\mathrm{mL}$ ekstrakt çözeltisi distile su ile seyreltilmiştir $(46 \mathrm{~mL}) .1 \mathrm{~mL}$ Folin-Ciocalteau çözeltisi ilave edilip, kap içeriği vortekslenmiştir. 3 dakika sonra $3 \mathrm{~mL} \mathrm{Na} \mathrm{CO}_{3}$ (\% 2) ilave edildikten sonra karışım 2 saat süresince aralıklı olarak çalkalanmıştır. $760 \mathrm{~nm}$ de absorbansı kontrol örneğine karşı ölçülerek, zeytin ekstraktlarındaki toplam fenolik madde konsantrasyonu standart gallik asit grafiğinden elde edilen aşağıdaki denklem yardımıyla mikrogram gallik 
asit eşdeğeri (GAE) cinsinden hesaplanmıştır;

Absorbans $=0.3456 \times$ toplam fenolik madde $(G A E, \mu g)-0.021$

\section{Sonuçlar}

\subsection{Linoleik asit emülsiyonunda toplam antioksidan aktivitenin belirlenmesi}

$\mathrm{Bu}$ çalş̧mada Türkiye'de ve Marmara Bölgesi'nde en çok yetiştiriciliği yapılan ve dolayısıyla en çok üretimi yapılan sofralık çeşitlerden Domat, Gemlik ve Edremit çeşidi zeytinler geleneksel üretim yöntemlerinden biri olan salamura değişimi ve endüstriyel yöntemler arasında en çok tercih edilen İspanyol Yöntemi kullanılarak sofralık zeytine işlenmişlerdir. Ham zeytin meyvesinde ve işlenmiş sofralık zeytin örneklerinin etanol ekstraktlarında toplam antioksidan kapasite belirlenmiştir. Bu amaçla oksidasyonun birincil metaboliti olan ve başlangıç aşamasında oluşan hidrojen peroksit konsantrasyonunun belirlenmesi esasıyla uygulanan ferriksiyanit method kullanılmıştır. Farklı ham zeytin örneklerine ait etanol ekstraktları $(250 \mu \mathrm{g})$ üzerine Linoleik asit emülsiyonunun peroksidasyon etkisi Şekil 1.'de gösterilmiştir. Ham zeytin örneklerine ait en yüksek antioksidan kapasite değeri sırasıyla Domat, Gemlik ve Edremit çeşitlerinde belirlenmiştir (Şekil 1). Bütün zeytin örnekleri tüm konsantrasyonlarda etkili antioksidan kapasite göstermişlerdir. Antioksidan bileşenler içeren ekstraktlarda bu maddelerin varlığ $\mathrm{Fe} 3+$ / ferrisiyanid kompleksinin demir forma indirgenmesine neden olur. Bu nedenle $\mathrm{Fe}^{+2}, 500$ nm'de belirlenebilir [8]. İspanyol yöntemiyle işlenmiş zeytin örneklerinde antioksidan aktivitede önemli kayıplar belirlenmiştir $(p<0.01)$ (Şekil 1).

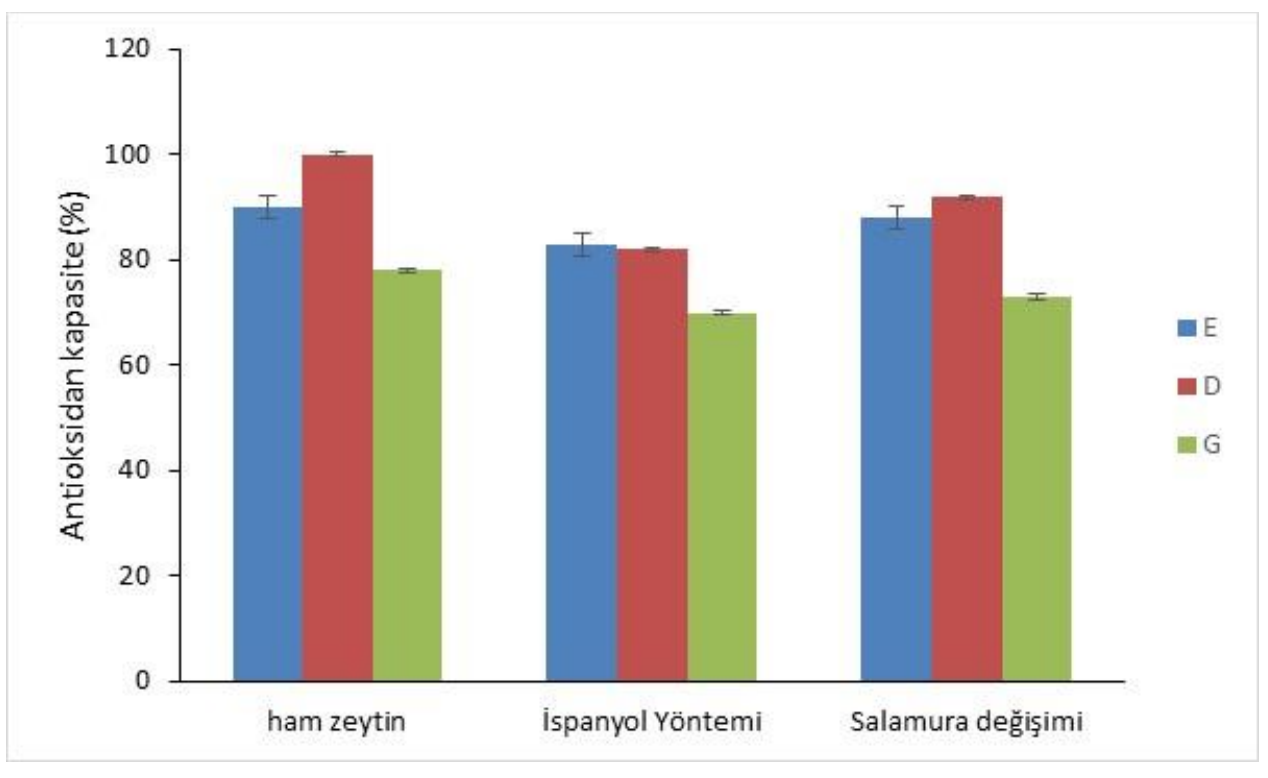

Şekil 1. Zeytin meyvesi ve salamura değişimi ile İspanyol yöntemi kullanılarak işlenmiş sofralık zeytinlerin etanol ekstraktlarındaki toplam antioksidan kapasite $( \pm \mathrm{SD}, \mathrm{n}=3)$. 


\subsection{Hidrojen peroksit giderme aktivitesi}

Farklı zeytin örneklerine ait etanol ekstraktlarının hidrojen peroksit giderme aktivitesi karşılaştırmalı olarak Şekil 2'de gösterilmektedir. Zeytin ekstraktlarının konsantrasyona bağlı olarak aktivitelerinin değiştiği belirlenmiştir. Ham zeytin örneklerine ait $1000 \mathrm{~mL}$ etanol ekstraktlarında Domat (D), Edremit (E), Gemlik (G) için antioksidan kapasite sırasıyla \%58, \%80, \%69 olarak belirlenmiştir. Aynı değer salamura değişimi ile elde edilen örneklerde Edremit (ES) \%38, ispanyol yöntemiyle elde edilen Edremit (EA) \%28, ispanyol yöntemiyle işlenen Gemlik çeşidinde (GA) \%15 ve İspanyol yöntemiyle işlenen Domat (DA) çeşidinde ise \%14 olarak belirlenmiştir. Bu örneklerde hidroje proksit giderme aktivitesi sırasıyla $E>G>D>E S>G S>D S>E A>G A>D A$ olarak değişmiş̧ir.

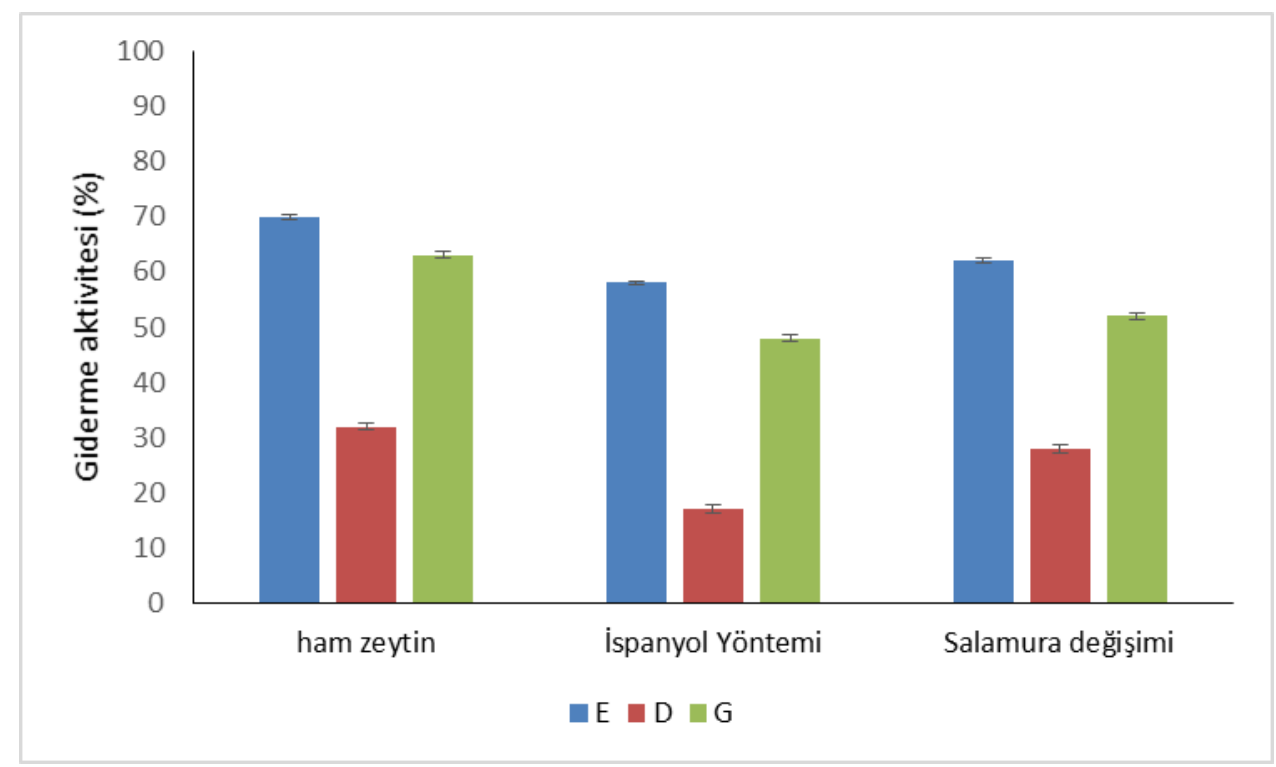

Şekil 2. Ham zeytin örnekleri ve iki farklı üretim yöntemiyle elde edilmiş sofralık zeytin örneklerine ait etanol ekstraktlarının aynı konsantrasyonlarda $(20 \mu \mathrm{g} / \mathrm{mL})$ hidrojen peroksit radikal giderme aktivitelerinin karşılaştırılması.

\subsection{Toplam fenolik bileşen}

Fenolik içerikleri (Tablo 1) incelenen zeytin çeşitlerinde ve bu çeşitler için taze ve işlenmiş zeytinler arasında önemli ölçüde farklılıklar ortaya konmuştur $(p<0.05)$. Bu içerikler taze zeytinlerde (Domat'ta $303.8 \mathrm{mg} \mathrm{GAE} 100 \mathrm{~g}^{-1}$, Edremit'te $402.2 \mathrm{mg}$ GAE.100 $\mathrm{g}^{\mathrm{g}-1}$ ), işlenmiş olanlara (Domat'ta $89.7 \mathrm{mg} \mathrm{GAE} 100 \mathrm{~g}^{-1}$ ileEdremit'te $312.5 \mathrm{mg} \mathrm{GAE}^{\prime} 100 \mathrm{~g}^{-1}$ ) göre daha yüksek bulunmuştur. 
Tablo 1. Zeytin örneklerinde toplam fenolik madde değişimi

\begin{tabular}{|c|c|c|c|}
\hline $\begin{array}{l}\text { Ürün } \\
\text { kodu }\end{array}$ & 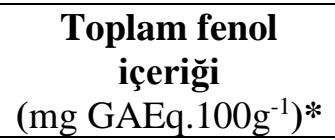 & $\begin{array}{c}\text { Fenol içeriğinde azalma } \\
(\%)\end{array}$ & $\begin{array}{c}\text { Bağıl fenol içeriği } \\
(\%)\end{array}$ \\
\hline D & $303.8 \pm 0.12$ & 0.00 & 100 \\
\hline DA & $89.7 \pm 1.2$ & 70.47 & 29.52 \\
\hline DS & $225.7 \pm 2,1$ & 25.70 & 74.29 \\
\hline $\mathbf{E}$ & $402.2 \pm 3.56$ & 0.00 & 100 \\
\hline EA & $118.6 \pm 2.17$ & 70.51 & 29.49 \\
\hline ES & $312.5 \pm 1.1$ & 22.30 & 77.70 \\
\hline $\mathbf{G}$ & $315.4 \pm 2.7$ & 0.00 & 100 \\
\hline GA & $159.1 \pm 3.1$ & 50.44 & 50.44 \\
\hline GS & $225 \pm 2$ & 28.44 & 71.4 \\
\hline
\end{tabular}

\section{Tartışma}

Zeytin ve zeytin ürünleri içerdikleri fenolik antioksidanlar nedeni ile "fonksiyonel gıda" olarak tanımlanmaktadır. Türkiye pazarında bulunan birçok sofralık zeytin üretim yöntemlerine bağlı olarak farklı düzeylerde fenolik antioksidan madde içeriğine sahiptir. Zeytinyağında antioksidan içeriklerinin üretim yöntemiyle bağlantısı inceleme konusu olmuşken sofralık zeytinlerin üretim yöntemleri ile içerdikleri antioksidan madde varlıkları arasındaki ilişki inceleme konusu olmamıştır [23]. Geleneksel olarak üretilen sofralık zeytinler ile endüstriyel yöntem olarak bilinen İspanyol yönteminin sofralık zeytin işlemede zeytinin içerdiği antioksidan ve toplam fenolik madde varlığına etkisi tüketicilerin sofralık zeytin seçiminde nütrüsyonel beklentinin karşılanması amacıyla önemli bulunmaktadır.

Zeytin meyvesinde antioksidan aktiviteyi oluşturan bileşenler çeşit, iklim, yöre, olgunluk düzeyi, hastalık ve zararlıların etkisi ile işleme yöntemi gibi pek çok faktörün etkisindedir. Saura-Calixto ve Goni (2006) fenolik bileşenlerin başlıca besinsel antioksidan kaynağ 1 olduklarını, ancak birçok biyolojik faktörün bu bileşiklerin bioyarayışlılıklarını etkilediğini belirtmişlerdir [24]. Ben Othman ve ark. (2009) üç farklı olgunluk düzeyinde "Chetoui" çeşidi zeytinlerin spontan ve kontrollü fermentasyonla işlenmesi sonrasında antioksidan aktivitesinde \%50-72 düzeylerinde azalma meydana geldiğini belirtmişlerdir [1].

Araştırmamızda kullanılan üç farklı zeytin çeşidi ve her iki işleme yöntemi göz önüne alındığında; ekstrakt konsantrasyonu arttıkça aktivitenin de arttığı belirlenmiştir. Zeytin ve ürünlerindeki antioksidan aktivite, fenolik madde içeriği ile ilişkilendirildiği için araştırmamızda fermentasyon süresince toplam fenolik madde miktarı ve antioksidan aktivite değişimi değerlendirilmiştir. Tüm konsantrasyonlarda $(10-1000 \mu \mathrm{L})$ etanol ekstraktları içerisinde ham zeytinlerin işlenmiş sofralık zeytinlerden daha yüksek antioksidan aktivite gösterdiği belirlenmiştir. İspanyol işleme yöntemi ve salamura değişimi ile elde edilen sofralık zeytinler, polar grupların oluşturduğu fenolik madde kayıpları ile 
antioksidan aktivitede düşmeye neden olmuştur. Uccella (2000) ispanyol işleme yöntemi ile pericarp ve mezokarpta bulunan pekçok fenolik maddenin alkali ile işleme ve yıkama işlemlerinden olumsuz etkilendiğini ve antioksidan madde kayıplarının bu işleme yönteminde arttığını bildirmiştir [11]. Bianchi (2003) fenolik madde kayıplarının işleme yöntemine göre değiştiğini ispanyol yöntemi ile işleme sırasında meydana gelen kayıpların hem polar hem de apolar fragsiyonlarda gerçekleştiğini ifade etmektedir [14]. Bütün ekstraktlarda antioksidan aktiviteler değerlendirildiğinde çeşitler içerisinde Domat çeşidinin Edremit ve Gemlik çeşidinden daha yüksek aktivite gösterdiği belirlenmiştir. Yöntemler karşılaştırıldı̆̆ında salamura değişimi ile elde edilen sofralık zeytinlerin genel olarak ispanyol yöntemi ile işlenen örneklere göre daha yüksek aktivite gösterdikleri belirlenmiştir. Ayrıca salamura değişimi yöntemi ile elde edilen sofralık zeytin çeşitleri arasında en yüksek antioksidan kapasite Domat (DS) ta belirlenmiş, bunu sırasıyla Edremit (ES) ve Gemlik (GS) izlemiştir. Domat meyve et/çekirdek oranı yüksek çeşitler arasında olup, büyüklüğüne göre kabuk kalınlığı fazla olmayan bir çeşit olarak bilinmektedir. Antioksidan madde miktarındaki azalmanın sebebi olarak bileşenlerin su ile işleme sırasında meydana gelen hidroliz ve ardısıra gerçekleşen daha küçük molekül büyüklüğüne sahip polar parçalanma ürünlerinin geçirgenliği fazla olan epidermis tabakasından geçerek meyveden azalması olarak tahmin edilmektedir. Buna karşın daha kalın bir kabuk yapısına sahip olan Edremit ve Gemlik çeşitlerinde polar fragsiyonların geçişi kabuk yapısı ve yağ içeriği yüksek bu çeşitlerin su ile işleme sırasında polar geçirgenliği zayıf olan kabuk yapısı nedeniyle tutulduğunu düşündürmektedir.

İspanyol yöntemi en önemli işlem basamaklarından birisi olan alkali ile acılık giderme sırasında $\mathrm{NaOH}$ epikarpta bulunan reaktif bileşenler ile reaksiyona girerek, vaks yapısındaki bu maddelerin çözülerek uzaklaşmasına neden olmaktadır. Bu, kullanılan alkali konsantrasyonu ve uygulama süresine bağlı olarak meyve etinden çekirdeğine dek etki etmektedir. Böylelikle zeytin meyvesinin epikarp ve mezokarp tabakası tamamiyla modifikasyona uğramaktadır. Daha dış kısımda yer alan kütiküla tabakasının kalınlığı ve sertliği işlem sırasında azalmakta ve yumuşama meydana gelmektedir. Böylelikle bu tabaka meyvenin dış tabakalarının daha geçirgen hale geleceği ve epidermal hücrelerin görünür hale geleceği ölçüde azalmaktadır. Sonuç olarak, bağlayıcı işlevi olan bu altta yatan hücreler, meyvelerin doku kıvamını olumsuz yönde etkileyen değişikliklere uğrarlar (Bianchi, 2003). İspanyol yöntemi ile ilgili olarak, birkaç çalışma, konjuge fenolik bileşiklerin fonksiyonel gruplarının seçici bir şekilde saldırıya uğradığını ve bileşen moleküler kısımlarının elde edildiğini göstermiştir. Bu nedenle, sodyum hidroksitin oleuropein üzerindeki etkisi, hidroksitirozol arasındaki ester grubu olarak oleoside 11-metilester ve hidroksi tirozol verir. Oleoside 11-metilester, karbometoksi grubu değişmeden kalırken parçalanır. Bununla birlikte, reaktiflerin uygun bir $\mathrm{pH}$ ve molar oranının olduğu $\mathrm{NaOH}$ ve oleuropein arasında sözde bir teknolojik reaksiyonda, daha az reaktif karbometoksi grubu ayrica bikarboksilik oleosid üretimine neden olacak şekilde hidrolize edilir [6, 14, 26, 27]. $\mathrm{NaOH}$ işleminden sonra kalan fenoller fermantasyonun gelişimini etkiler. Fermantasyon sırasında, bakterilerin yetersiz büyümesi nedeniyle, $\mathrm{pH}$ 'ta istenen düşüş her zaman elde edilemez. Fermentasyonu olumsuz etkileyen bu gibi problemler tüm oleuropein izlerini gidermek için yetersiz ön alkali işleminden, degradasyon ürünlerinin varlığından, substratta yeterli miktarda şeker bulunmamasından ve salamuranın tuz içeriğinden kaynaklanabilir[26].

Zeytinyağı ekstraktlarında hidrojen peroksit giderme aktivitesi ile ilgili pekçok araştırma 
mevcut iken farklı üretim yöntemleri ile elde edilen sofralık zeytinlere ilişkin yeterli veri bulunmamaktadır. Elde edilen sonuçlar toplam antioksidan kapasite verileri ile uyuml bulunmuştur.

Denemelerde kullanılan zeytin çeşitlerinin toplam fenolik madde içeriklerindeki değişim hammaddeden sofralık zeytine işlenme srecnde önemli ölçüde azalmıştır. Bu sonuç uygulanan acılık giderme işlemlerinde kullanılan alkali uygulaması ile salamura değişimi sonucunda ortaya çıkmaktadır. Tunus [25], İtalyan [29] ve Cezayir [30] gibi farklı coğrafyalarda yetişen çeşitlere ait toplam fenolik madde içeriklerinin, araştırmamızda kullanılan çeşitlere göre daha yüksek olduğu belirtilmekte ve işleme sırasında bu maddelerin farklı oranlarda kayıplarından da söz edilmektedir. Sofralık zeytin, Akdeniz Diyeti'nin temel besin bileşeni olan fenolik bileşenler ve onların hidroliz ürünlerinin alınmasında önemli bir kaynaktır [17]. Kountouri ve ark. (2007) gönüllü insan denemelerinde zeytin fenoliklerinin biyoyarayışlılığını araştırdıkları çalışmalarda, plazma fenolik madde içeriğindeki artışın, zeytin tüketimi ile ilgili olduğunu belirlemişlerdir [31]. Sonuçlar, zeytin fenolik bileşenlerinin iyi biyoyarayışlılık etkisine sahip olduğunu, dolayısıyla antioksidan etkinliğinin de yüksek olduğunu göstermektedir. Zeytin işleme sırasında meyvede bulunan, suda çözünebilen şekerler, $\mathrm{NaCl}$ ve fenolik bileşen içeriklerinde salamurada meydana gelen ozmotik değişim nedeniyle değişimler oluşmaktadır [13]. Fenolik bileşikler, hidroksil grupları nedeniyle radikal giderme aktiviteleri yüksek olan çok önemli bitki bileşenleridir [32]. Saura-Calixto ve Goni (2006), İspanyol diyetinin fenolik içeriği ve antioksidan kapasitesini incelemişler ve findık, meyve, sebze, baklagiller ve hububattaki toplam fenol miktarlarını sırasıyla 894, 538, 287, 155 ve $107 \mathrm{mg} / 100$ g kuru madde olarak belirlemişlerdir [24]. Aynı araştırıcılar, İspanya'da toplam fenolik alımının kişi başına günde $1171 \mathrm{mg}$ gallik asit olduğunu Folin-Ciocalteu yöntemiyle tahmin etmektedirler [24]. Bazı araştırıcılar, toplam fenol içeriği, ana antioksidan bileşiklerin (toplam polifenoller) içeriği ile zeytin örneklerinin toplam antioksidan kapasitesi arasında korelasyonn olduğunu belirtmektedirler [25-33]. Ancak bazıları bu görüşün tersini savunmaktadırlar [34]. Bu veriler, yüksek toplam polifenol içeriğinin, antioksidan aktiviteyi arttırdığını ve fenolik içerik ile antioksidan aktivite arasında doğrusal bir korelasyon olduğunu gösteren görüşü desteklemektedir.

Diyet antioksidanlarının, Akdeniz diyetinin faydalı etkilerinin kritik bir aracısı olabileceğine dair gittikçe artan bilimsel kanıtlar vardır. Akdeniz diyeti araştırmaları, yağ polifenollerinin önemli sağlık yararları sağladığını göstermektedir. Polifenoller serbest radikalleri absorplayarak, kardiyovasküler hastalık ve bazı kanser türleri üzerinde önleyici etkiye sahiptir. Ayrıca klinik çalışmalarda onaylandığı gibi antiinflamatuar olarak da işlev görürler. Böylesine işlevsel bir etkiye sahip iyi antioksidan kaynağı besin tüketimi Akdeniz diyetinin temelini oluşturmaktadır. Ancak inanılanın aksine, zeytin bazı üretim aşamalarında sağlıklı bileşenlerini kaybedebilmektedir. Sofralık zeytin üretiminde antioksidan özelliklerin kaybolmasından sorumlu en önemli adım acılık giderme sürecidir. İspanyol yöntemiyle işlenen zeytinlerin etanol ekstraktları, salamura değişimi yöntemiyle işlenen zeytinlere göre daha zayıf antioksidan aktivite göstermiştir. Fenolik madde içeriğindeki azalma İspanyol Yöntemi ile işlenen zeytin örneklerde daha fazla bulunmuştur. Ham zeytin numuneleri arasındaki farklar çeşit, olgunlaşma varyasyonu ile açıklanmıştır. Elde edilen sonuçlar, zeytin işlemenin, toplam fenolik içeriğinde önemli bir kaybı indüklediğini ve antioksidan değerinde bir azalmaya yol açtığını göstermektedir. Günümüzde fonksiyonel gıdalar büyük 
öneme sahip olduğundan, fenolik kaybı düşük yeni bir sofralık zeytin üretim yöntemine odaklanmak gerekmektedir.

\section{Kaynaklar}

[1] Ben Othman N., Roblain D., Chammen N., Thonart P., and Hamdi M. Antioxidant phenolic compounds loss during the fermentation of Chetoui olives. Food Chemistry. 116, 662-669, (2009).

[2] Marsilio, V., Campestre, C., and Lanza, B., Phenolic compounds change during California-style ripe olive processing. Food Chemistry. 74,55-60, (2001).

[3] Rice-Evans, C.A., Miller, N.T., Paganga, G., Antioxidant properties of phenoliccompounds. Trends in Plant Science. 2 (4), 152-159, (1996).

[4] Ayar-Kayal, H., Urek, R.O., Nakiboğlu, M., \& Tarhan, L. Antioxidant Activities of Endemic Sideritis Leptoclada and Mentha Dumetorum Aqueous Extracts Used In Turkey Folk Medicine. Journal of Food Processing and Preservation, 33, 285295, (2009).

[5] Lee, J.M., Chung, H., Chang, P.S., and Lee, J.H., Development of a method predicting the oxidative stability of edible oils using 2,2-diphenyl-1-picrylhydrazyl (DPPH),Food Chemistry. 103, 662- 669, (2007).

[6] Visioli, F., Poli, A., and Galli, C., Antioxidant and other biological activities of phenols from olives and olive oil. Medicinal Research Reviews, 22,65-75, (2002).

[7] Lai, L.S., Chou, S.T., and Chao, W.W., Studies on the antioxidative activities of Hsian-tsao (Mesona procumbens Hemsl) leaf gum, Journal of Agricultural and Food Chemistry, 49:963-968, (2001).

[8] Gülçin, İ., Büyükokuroğlu, M.E. and Oktay, M., On the in vitro antioxidant properties of melatonin, Journal of Pineal Research, 33, 167-171, (2006a).

[9] Miller, N. J., Diplock, A. T., and Rice-Evans, C.A., 1995. Evaluation of the total antioxidant activity as a marker of the deterioration of apple juice in storage.Journal of Agricultural and Food Chemistry, 43, 1794-1801, (1995).

[10] Pereira, J.A., Pereira, A.P.G., Ferreira, I. C. F. R., Valentao, P., Andrade, P. B., Seabra, Estevinho, R.L., and Bento, A., 2006. Table olives from Portugal: Phenolic compounds, antioxidant potential, and antimicrobial activity. Journal of Agriculture and Food Chemistry, 54, 8425-8431, (2006).

[11] Uccella, N., 2000. Olive biophenols: novel ethnic and technological approach. Trends in Food Science and Technology. 11,328-339, (2000).

[12] Bouzaziz, M., Chamkha, M., and Sayadı S., Comparative Study on Phenolic Content and Antioxidant Activity during Maturation of the Olive Cultivar Chemlali from Tunisia. Journal of Agriculture and Food Chemistry, 52,5476-5481, (2004).

[13] Patumi, M., d_Andria, R., Marsilio, V., Fontanazza, G., Morelli, G., and Lanza, B., Olive and olive oil quality after intensive monoclone olive growing (Olea europaea L., cv. Kalamata) in different irrigation regimes. Food Chemistry, 77, 27-34, (2002).

[14] Bianchi G., Lipids and phenols in table olives. European Journal of Lipid Science and Technology. 105, 229-242, (2003).

[15] Blekas G, Vassilakis C, Harizanis C, Tsimidou M, Boskou D-G., Biophenols in table olives. Journal of Agricultural and Food Chemistry, 50, 3688-3692, (2002).

[16] Romero, C., Garc1'a, P., Brenes, M.; Garc1'a, A., and Garrido, A., 2002. Phenolic 
compounds in natural black Spanish olive varieties. European Food Research and Technology, 215, 489-496, (2002).

[17] Boskou G, Fotini N, Salta Chrysostomou S, Mylona A, Chiou A, Andrikopoulos NK. 2006. Antioxidant capacity and phenolic profile of table olives from the Greek market. Food Chemistry. 94, 558-564, (2004).

[18] Hui, Y.H., Barta, J., Cano, M.P., Drake, S.R. Gusek, T.W., Sidhu, J.S., and Sinha, N., 2006. Olive processing. Iowa, USA: Blackwell publishing. 26, 491-517, (2006).

[19] Romero, C., Brenes, M., Yousfi, K.; Garcia, P., Garcia, A., and Garrido, A., Effect of cultivar and processing method on the contents of polyphenols in table olives. J. Agric. Food Chemistry, 52, 479-484, (2004).

[20] Gulcin, I., Elias, S.R., and Gepdiremen, A., Antioxidant activity of lignans from fringe tree (Chionanthus virginicus L.), European Food Research and Technology, 223: 759-767, (2006b).

[21] Ruch, R.J., Cheng, S.J., and Klaunig, J.E., Prevention of cytotoxicity and inhibition of intracellular communication by antioxidant catechins isolated from Chinese green tea, Carcinogenesis 10, 1003-1008, 1989.

[22] Singleton, V.,L., Orthofer, R., Ramuela -Raventós,R.M., Ester, P., Analysis of total phenols and other oxidation substrates and antioxidants by means of Folin-Ciocalteu reagent. Methods in Enzymology, 299, 152-178, 1999.

[23] Kachouri, F., Ksontini, H., Kraiem, M., Setti, K., Mechmeche, M. and Hamdi, M., Involvement of antioxidant activity of Lactobacillus plantarum on functional properties of olive phenolic compounds, Journal of Food Science and Technology, 52(12): 7924-7933, (2015).

[24] Saura-Calixto, F., and Gonii, I., 2006. Antioxidant capacity of the Spanish Mediterranean diet. Food Chemistry, 94: 442-447, (2006).

[25] Ben Othman, N., Roblain, D., Thonart, P., and Hamdi, M., Tunisian table olivephenolic compounds and their antioxidant capacity. Journal of Food Science, 73, 4,235-240, (2008).

[26] Soler-Rivas, C., Esp1 'n, J. C., Wichers, H. J., 2000. Oleuropein and related compounds. Journal of the Science of Food and Agriculture. 80: 1013-1023.

[27] Capozzi, F., Piperno, A., and Uccella, N., Oleuropein site selective hydrolysis by technomimetic NMR experiments. Journal of Agricultural and Food Chemistry 48,1623-1629, 2000.

[28] Yıldız, G., Uylaşer, V. 2015. Profile and total content of phenolics and antioxidant activity of commercial table olives from Turkey. Quality Assurance and Safety of Crops \& Foods, 5, 635 - 642, (2015).

[29] Piscopo A, De Bruno A, Zappia A, Poiana M., Antioxidant activity of dried green olives (Caroleacv.). LWT-Food Science and Technology. 58, 49-54, (2014).

[30] Mettouchia, S., Sacchib, R., Ould Moussaa, Z.E.D., Paduanob, A., Savaresec, M. and Tamendjaria, A.,Effect of Spanish style processing on the phenolic compounds and antioxidant activity of Algerian green table olives, Grasas Y Aseites, 67 (1), e114, (2016).

[31] Kountouri, A.M., Mylona, A., Kaliora, A.C., and Aandrikopoulos, N.K., Bioavailability of the phenolic compounds of the fruits (drupes) of Olea europaea (olives): Impact on plasma antioxidant status in humans. Phytomedcine, 14, 659667, (2007).

[32] Hatano, T., Edamatsu, R., Mori, A., Fujita, Y. and Yasuhara, E., Effect of interaction 
of tannins with co-existing substances. VI. Effects of tannins and related polyphenols on superoxide anion radical and on DPPH radical. Chemical and Pharmaceutical Bulletin, 37,2016-2021, (1989).

[33] Gorinsteina, S., Martin-Bellosob, O., Katricha, E., Lojekc, A., Ćíź, M., GligelmoMiguelb, N., Haruenkitd, R., Parke, Y.S., Jungf, S.T., and Trakhtenbergg, S., Comparison of the contents of the main biochemical compounds and the antioxidant activity of some Spanish olive oils as determined by four different radical scavenging tests. Journal of Nutritional Biochemistry, 14, 154-159, (2003).

[34] Yu, L., Haley, S., Perret, J., Harris, M., Wilson, J., and Qian, M., Free radical scavenging properties of wheat extracts. Journal of Agricultural and Food Chemistry50, 1619-1624, (2002). 